\title{
A Look at Ten Months of Price-Wage Controls
}

\author{
Remarks by \\ LEONALl C. ANDERSEN, Senior Vice President, \\ Federal Reserve Bank of St. Louis, \\ Before the Eastern Missouri Member Bankers,
}

St. Louis, Missouri, June 14, 1972

0

N AUGUST 15, 1971, the U.S. economy entered into a situation unparalleled in its history. A system of price and wage controls was instituted during a period of considerable economic slack. Previously, such extensive controls had been used during periods when demand for goods and services exceeded the economy's ability to meet the demand. While the pricewwage guideposts of the early 1960 s also occurred during a time of considerable economic slack, those measures did not represent as vigorous an attempt to control the pace of price and wage advances as the present effort.

The New Economic Plan has also called for stimulative actions to promote an accelerated recovery from the recent recession. Since August the pace of economic expansion has definitely quickened. For example, industrial production has grown at an 8 percent rate since last August, compared with a 3.5 percent rate of increase from the business cycle trough in late 1970 to last August. Employment increased at a 3.7 percent rate from August to May, a marked contrast to virtually no growth in the preceding nine months.

While there is general agreement that the recovery is undergoing a vigorous expansion, considerable concern has been expressed regarding the contribution of the established system of price-wage controls to a reduction in the rate of inflation. My remarks today will be concerned mainly with an evaluation of this question.

Ten months have now passed since the start of the attempt to slow, by a system of price-wage controls, the stubborn inflation of the last seven ycars. We have had only limited experience with this control system to date, so any evaluation of its contribution thus far will have to be tentative. My reading of the record since last August leads me to conclude that there is little support for the proposition that the rate of inflation has been reduced considerably from what it would have been in the absence of the program.

Before presenting the details of my evaluation, I will provide a brief summary of the general view of the inflationary process which underlies the present control system. This background will then be used to evaluate the record of the fight against inflation since last August. Later in my remarks I will present an alternative view of the basic causes of inflation and will use this view in assessing the possible contribution of controls to promoting price stability.

\section{The General View of Inflation and Controls}

A large majority of economists have arrived at a generally accepted view of the forces which underlie the inflationary process. Changes in the price level, it is argued, result basically from a mark-up of unit labor costs. Events underlying changes in the level of wages relative to changes in labor productivity are considered important factors in the determination of changes in unit labor costs and, hence, movements in the price level. In addition, forces which alter the mark-up of costs are viewed as other important causes of inflation.

Wage movements, according to this view, are greatly influenced by the amount of economic slack in existence at any point in time. The greater the slack, frequently measured by a high unemployment rate, the slower wages are expected to rise. On the other hand, a high degree of resource utilization is expected to lead to more rapidly rising wages. 
Productivity, or output per manhour, grows overtime at a trend rate determined by advances in technology, accumulation of capital, and increased skill and training of the labor force. Productivity also exhibits short-run movements, rising rapidly as the economy moves upward from the trough of the business cycle and slowly as a cycle peak is approached.

Wages and productivity are constantly changing relative to each other, and these movements, in turn, produce movements in the price level. For example, an increase of wages in excess of productivity gains, according to this widely accepted view, increases unit labor costs, thereby producing a rising level of prices.

This view argues that inflation stems from two primary sources. The first source is a great expansion in demand for goods and services which leads to a high level of resource utilization, or put another way, low unemployment. Growth of aggregate demand leads to an expansion of demand for labor. As a result, wages rise faster than productivity gains, producing a rise in the price level. This is the so-called "demandpull" inflation.

The second source of inflation is believed to be the exercise of monopoly power by labor unions and large corporations. Labor unions, it is argued, have the power to achieve wage increases in excess of productivity gains. Large business firms are considered to have the power to control the mark-up applied to costs in setting prices for their products. A rise in prices from monopoly power is frequently referred to as "cost-push" inflation. In recent years, this explanation has been used to account for continued inflation, even though considerable slack was present in the economy.

Let us now examine how this generally accepted view regarding the inflationary process has shaped the present price-wage control program. I want to emphasize that the present effort to control inflation is to be accompanied by monetary and fiscal actions designed to rapidly expand the demand for goods and services and thereby lower the unemployment rate. According to the preceding analysis, such a result would be expected, in time, to exert upward demand pressure on prices. In addition, at the time the controls were initiated, it was believed that cost-push forces would remain strong for some time to come. Thus, price-wage controls are an integral part of an overall plan to promote rapid expansion of employment and at the same time reduce inflation.

The control program is, therefore, based on two central ideas - controlling wage increases and limiting the price mark-up of the costs of goods and services. Wage increases are to be based on a set of guidelines.
Price increases are to reflect primarily a percent passthrough of increases in costs, with wage costs being reduced by gains in productivity. A limit is set for each business firm's profit margin, thereby limiting its ability to increase its average mark-up of costs in setting prices of its products.

\section{A Look at the Period Since August 15}

Let us now examine the record since last summer for an evaluation of the contribution of the present: system of controls to reducing inflation. Two questions: need to be answered in arriving at an evaluation. First, have wage and price advances actually slowed? Second, if some slowing has occurred, has it been greater than would have occurred in the absence of the program?

\section{Has Inflation Decelerated?}

There is no doubt that during Phase I price and wage advances came to a virtual halt and that since the beginning of Phase II, these advances have been substantial in most instances. Since a post-Phase $I$ bulge was expected, I will compare the record over both phases - that is, since last August, with the record just prior to Phase $I$. In making this comparison, I will examine comparative movements within broad measures of wages, unit labor costs, and prices, rather than make comparisons in terms of adherence to established guidelines or the scaling down of major labor contract settlements. After all, it is the actual performance of key economic data series which is of foremost concern. Selection of time periods are crucial in making an evaluation, and so as not to overstate my case, I have selected periods which give the most favorable interpretation to the program.

The record since last August indicates that some slowing has occurred in the rate of advance in employee compensation, and that this slowing has reduced to some degree the upward pressure on prices from the labor cost side. Employee compensation includes both wages and the cost of fringe benefits. The best over-all measure of employee compensation, private hourly earnings in nonagricultural employment (adjusted for overtime and interindustry shifts), rose at a 6.2 percent annual rate from August to May. By comparison, the rate of increase during the six months prior to the inflation control program was almost 7 percent.

This slowing in the growth of employee compensation, along with a slight increase in productivity growth, has reduced somewhat the rate of increase in unit labor costs, a key link in the widely accepted 
view of the inflationary process. Unit labor costs increased at a 3 percent rate from the second quarter of last year to the first quarter of 1972 , compared with a 4 percent rate of increase in the preceding three quarters.

An examination of over-all price behavior since just before the program shows some slowing in the rate of inflation. Our broadest measure of price movements in the economy, the GNP deflator, rose at a 3.4 percent rate from the second quarter of 1971 to the first quarter of 1972 , compared with a rate of about 5 percent in the preceding three quarters. Although some slowing in the rate of advance of wholesale and consumer prices has occurred since February, the time is too short to conclude that their very rapid rates of increase from November to February were merely a temporary bulge following the freeze and that future advances will be less than in the six months prior to last August.

\section{Has Inflation Been Slowed More Than Without Controls?}

Now that we have observed some evidence that the over-all rate of inflation has subsided from the rate preceding last August, let us examine the proposition that the slowdown is greater than it would have been in the absence of the controls. There is evidence which suggests that such a development has not occurred.

The rate of inflation was slowing prior to the freeze, reaching a peak sometime in 1970 and then receding slowly. For example, the consumer price index rose 4.4 percent in the year ending last August, down from the 5.6 percent in the preceding twelve months. The GNP deflator had started to rise at a somewhat slower rate after early 1970 . For some time prior to last summer, the rate of advance in the wholesale price index was generally stabilized. Of course, all of these series showed temporary upward surges, especially wholesale and consumer prices, in May and June of last year.

The above evidence suggests that there were downward pressures on inflation in existence prior to the adoption of controls. Morever, historical relationships indicate that a further slowing in 1971 and early 1972 could have been expected. Using such relationships, a large number of economic forecasters in early 1971 had projected a further reduction in inflation during the balance of 1971 and into 1972 ; these projections were not based on any assumption of controls over wage and price movements.

For example, the American Statistical Association reported a survey of about fifty forecasts made shortly before the imposition of price-wage controls. The average rate of inflation, measured by the GNP deflator, projected by this group of forecasters for the second quarter of 1971 to the first quarter of 1972 was 3.5 percent. This indicated an expected decline from the 5 percent increase in the preceding four quarters. Moreover, the average rate projected by this group of forecasters turned out to be the actual rate of increase.

\section{Conclusions from the Record}

This examination of the record since last August indicates that some reduction in the rate of inflation has occured. The record, however, gives little support to the proposition that the rate of inflation has been reduced considerably from what it would have been in the absence of the price-wage program.

\section{An Alternative View of Inflation and Controls}

At this time, I will briefly outline another view of the cause of inflation which differs substantially from the one underlying Phase II controls, but which is consistent with the cost and price behavior we have observed. This is necessary, I believe, in order to get a proper evaluation of Phase II.

\section{The Monetary View of Inflation}

This view argues that inflation is primarily a monetary phenomenon; that is, the rate of inflation is ultimately determined by the trend growth of the nation's money stock over several years. It is further argued that the cost-push phenomenon is merely a part of the inflationary process, rather than an independent cause. The monopoly power argument is, therefore, rejected as an independent cause of inflation. This view is held by a growing number of economists, including your speaker, but it still remains a minority view.

Let us analyze the inflation record since the early $1950 \mathrm{~s}$ from this viewpoint. The money stock, defined as demand deposits and currency held by the nonbank public, grew at a 2 percent annual rate from the first quarter of 1952 to the third quarter of 1962. Then, the trend rate of money growth was accelerated to a 4 percent rate to the end of 1966 . It was further accelerated to a 6 percent rate, which has continued to the present time.

There was a period of relative price stability from the first quarter of 1952 to the end of 1965 . During this period, prices, measured by the GNP deflator, 
rose at a very moderate 2 percent trend rate. Following the acceleration of the trend growth rate of money, prices rose at a 4 percent rate from the end of 1965 to mid-1969. Next, after another hike in the trend rate of money growth, prices rose faster - at about a 5 percent rate from mid-1969 to the price freeze.

We have been conducting considerable empirical research into the response of the rate of inflation to a change in the rate of monetary expansion. This research indicates that the trend rate of monetary expansion is the dominant factor underlying the inflationary process. It also indicates that the response of inflation to a change in the trend rate of money growth takes from five to seven years to be fully manifested.

\section{Implications of the Monetary View for Controls}

This monetary view, to the extent that it is valid, has some important implications for evaluating Phase II. First, this view states that the present program attacks the symptoms of inflation, and not the basic cause - the rapid 6 percent trend rate of growth in money since late 1966. Second, since this rapid trend rate of monetary expansion has persisted for over five years, the economy has about fully adjusted to it, and no lasting reduction in inflation will occur until money grows at a slower pace.

It is our estimate that, at a minimum, a 4 percent basic mate of inflation is implied by the monetary experience since 1966. Some short-lived improvement in this rate of inflation may result as output of goods and services expands rapidly this year. Such an expansion would produce productivity gains, and as a consequence, some improvement in price performance may be noted. However, as the economy approaches a high level of employment, productivity gains will again taper off and inflation will accelerate to about 4 percent.

Consequently, inflation may recede during the balance of 1972, giving the appearance of success to Phase II. If there is a desire, however, to produce continued improvement and there occurs no reduction in the trend rate of monetary expansion, controls will have to become tougher and tougher. This situation would have to continte, according to the monetary view, until the basic cause of inflation is treated instead of just the symptoms.

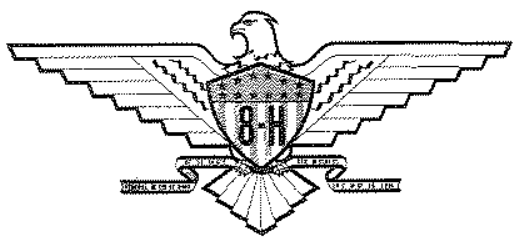

